\title{
Plant density and water management effect to leaf folder and narrow brown spot severity in irrigated rice
}

\author{
Arlyna B. Pustika*, and Mahargono Kobarsih \\ Assessment Institute of Agricultural Technology of Yogyakarta, Jl. Stadion Maguwoharjo No. 22 \\ Ngemplak, Sleman, Yogyakarta, Indonesia
}

\begin{abstract}
Rice Leaf Folder and Narrow Brown Spot cause yield losses of rice production. Environmental factors are suggested effects the severity of them. This research was aimed to determine the effect of plant density and water management to the severity of these pest and disease in the agro ecosystem of irrigated paddy field. Research was conducted using Inpari 44 variety in Godean Sleman Yogyakarta, April to July 2020. Experimental design was randomized block design with 4 treatments and 4 replications. Treatments were plant density (high $=50 \mathrm{~kg} \mathrm{ha}^{-1}$ and low $=25$ $\mathrm{kg} \mathrm{ha}^{-1}$ ) and water management (alternate wetting and drying/AWD, and continues flooding). Results showed that highest attack intensity of leaf folder $(25 \%)$ was occurred in 42 nd days after planting in high plant density with AWD. Meanwhile, highest severity of narrow brown spot (58\%) was found in 63rd days after planting in plant with low density and continues flooding. High leaf folder attack intensity was caused by high plant density, but not effected by water management. At the other side, high severity of narrow brown spot was affected by water management, but not effected by plant density.
\end{abstract}

\section{Introduction}

Rice (Oryza sativa L.) is consumed as $90 \%$ by Indonesian people as the staple food. To feed the people, rice production should be increase $7 \%$ per year, while the production of Indonesian rice in 2019 was 54 million ton. Indonesian rice production relies on 7,463 million hectares paddy field area which is harvested as 10,677 million ha with the productivity was $5.114 \mathrm{t} / \mathrm{ha}$. To feed 268 million people and to obtain 1.5 - 2-million-ton rice surplus, Indonesia should produce 39.2-million-ton husked rice in 2020. In addition, Yogyakarta has 111 thousand hectares of harvested rice area and produced 533 thousand ton of rice (301 thousand ton of husked rice) in 2019. Yogyakarta rice productivity was $4.786 \mathrm{t} / \mathrm{ha}$ [1]. To increase Yogyakarta rice productivity, technical improvement should be conducted through some cultivation upgrading like water management and plant population adjustment.

* Corresponding author: arlynabudi@gmail.com 
Rice is susceptible to some diseases caused by fungi and bacteria [2]. Narrow brown spot caused by Cercospora oryzae Miyake confined to the reduction of the effective leaf surface of the plant and causes premature killing of leaves and sheath, and predisposes the plant to lodging. The disease produces short, linear, brown lesions with $2-10 \mathrm{~mm}$ long and $1 \mathrm{~mm}$ wide, most commonly on leaves. They tend to be narrower, shorter and darker brown on resistant cultivars and wider and lighter brown on susceptible ones [3]. The lesions usually appear in large numbers during the later stages of rice growth because they require 30 or more days for the symptom to appear after inoculation. This may account for the late appearance of the disease in field although young leaves are as susceptible as old leaves. Yield loss caused by this disease reach $10-40 \%[4,5,6]$. Humidity influences the disease development. The process of fungal sporulation in leaves increases during prolonged humid conditions [7].

Rice Leaf Folder, Cnaphalocrocis medinalis (Guenee) (Lepidoptera: Pyralidae) is one of predominant leaf feeding insect which one of the most destructive pests because their ability to defoliate and remove the chlorophyll in leaves leading the reduction of yield [8, 9]. The yield loss caused by this pest reach $30-80 \%[10,11]$. Longitudinally fold leaves was the specific damage caused by the larvae, whilst the second instars larvae glue the growing leaves longitudinally. They stitch the leaf margins and scrape the mesophyll within the folded leaves. It causes pale, linear white stripes, membranous patches and papery dry leaves, which may result stunting, curling or yellowing foliage [12, 13]. A single larvae may damage several leaves. Other study showed significant losses which is $17.5 \%$ damaged leaves resulted $16.5 \%$ yield loss, while $21.3 \%$ yield loss relates with $26.6 \%$ damaged leaves. Additionally, the extent of loss may reach $63-80 \%$ depends on the agro-ecological conditions $[14,15,16,17]$. Optimum temperature and high humidity are the important factors in affecting their abundance. Besides, scented and modern varieties, multiple rice cropping and new irrigation systems increase the problem of leaf folder [18].

\section{Method}

Research was conducted in Sidoluhur village, Godean sub district (-746’28”, 110 16'33”), Sleman, Yogyakarta, from April to July 2020. Rice varieties used in this research were Inpari 44, which was transplanted from 18 days seedling age. Experimental design was randomized block design with 4 treatments and 4 replications. Treatments were plant density (high $=50 \mathrm{~kg} \mathrm{ha}^{-1}$ and low $=25 \mathrm{~kg} \mathrm{ha}^{-1}$ ) and water management (alternate wetting and drying/AWD, and continues flooding). AWD was begun applied at plant age 14 days after transplanting (DAT), except a week before flowering until a week after flowering. Water level during wetting period was $5 \mathrm{~cm}$ above soil surface, then stop flooding to reach $15 \mathrm{~cm}$ water level below soil surface.

The 4 treatments were as follow:
A. High plant density with continues flooding
B. High plant density with AWD
C. Low plant density with continues flooding
D. Low plant density with AWD

The plant damage caused by Rice Leaf Folder and disease development of Narrow Brown Spot were observed at age 21st, 42nd, and 63rd of the rice plant. Larvae population and Attack Intensity of Rice Leaf Folder were determined using Direktorat Perlindungan Tanaman (2018). Disease severity of Narrow Brown Spot was determined using Standard Evaluation System (SES) for rice (IRRI, 1996). In addition to disease severity and 
percentage of damaged leaf, yield data were recorded by measuring grain weight based on Teknik Ubinan Jajar Legowo Super (Balai Besar Penelitian Padi, 2010).

Population's observation of Cnaphalocrosis medinalis was conducted by larva counting on leaf rolls sample then calculated by formula as follow:

$$
\mathrm{P}=\underline{\mathrm{a}}
$$

Where:

$\mathrm{P}=$ populations

$\mathrm{a}=$ larvae founded on sample

$\mathrm{b}=$ number of observations

Attack Intensity of Rice Leaf Folder were calculated using the formula:

$$
\mathrm{I}=\frac{\sum(\mathrm{n} \times \mathrm{v})}{\mathrm{N} \times \mathrm{V}} \times 100 \%
$$

Where:

$$
\begin{aligned}
\mathrm{I} & =\text { Attack Intensity } \\
\mathrm{n}_{\mathrm{i}} & =\text { Sample with damage of scale } \mathrm{v}_{\mathrm{i}} \\
\mathrm{V}_{\mathrm{i}} & =\text { scale of damage } \\
\mathrm{N} & =\text { Plant observed } \\
\mathrm{V} & =\text { Highest damage scale }
\end{aligned}
$$

Categorization of attack intensity is following:

$1=$ infestation intensity/damage $<25 \%$

$2=$ infestation intensity/damage between $25-50 \%$

$3=$ infestation intensity/damage between $50-75 \%$

$4=$ infestation intensity/damage $>75 \%$

Disease's severities of Narrow Brown Spot were calculated using the formula:

$$
\mathrm{DS}=\frac{\Sigma(\mathrm{ni} \times \mathrm{vi})}{\mathrm{N} \times \mathrm{V}} \times 100 \%
$$

Where:

DS = Severity of Disease

$\mathrm{n} \quad=$ Number of infected leaves

$\mathrm{v} \quad=$ Each category attack score value

$\mathrm{N}=$ Number of total observed leaves

$\mathrm{V}=$ The highest score value

Analysis of Variance (ANOVA) was used to analyse all data for the differences among treatments. Duncan Multiple Ranged Test $(\mathrm{DMRT})(\mathrm{p}=0.05)$ by the SAS statistical package was used for comparing the means.

\section{Result and discussion}

\subsection{Larvae leaf folder population}

Plant density and water management effect to the population of larvae leaf folder were presented in Table 1. Population of larvae leaf folder was highest ( 3 per 10 plants) in $21^{\text {st }}$ days after planting in high plant density with AWD. Larvae was firstly found at day $15^{\text {th }}$ after planting, then decreased when rice plant entering the generative phase. The abundance of this pest was occurred at tillering until the end of vegetative phase. The result suggested 
that high plant density treatment effected higher population of larvae than low plant density treatment. Moreover, the reduction of larvae population at day $63^{\text {rd }}$ was lower at high plant density and AWD treatment. It seems the larvae of leaf folder received favor condition for growing at high plant density and AWD condition. It might be related to the favor humidity and higher shading caused by high plant density [19].

Table 1. Population of rice leaf folder larvae per 10 plants at 21st, 42nd and 63rd DAT

\begin{tabular}{lccc}
\hline \multirow{2}{*}{ Plant Density and Water Management } & \multicolumn{3}{c}{ Plant age (DAT) } \\
\cline { 2 - 4 } & 21st & 42nd & 63rd \\
\hline High plant density with continues flooding & $0.5 \mathrm{ab}$ & $0.5 \mathrm{a}$ & $0.3 \mathrm{ab}$ \\
High plant density with AWD & $3.0 \mathrm{~b}$ & $1.5 \mathrm{~b}$ & $1.3 \mathrm{~b}$ \\
Low plant density with continues flooding & $0.1 \mathrm{a}$ & $0.5 \mathrm{a}$ & $0.1 \mathrm{a}$ \\
Low plant density with AWD & $0.1 \mathrm{a}$ & $0.5 \mathrm{a}$ & $0.1 \mathrm{a}$ \\
\hline
\end{tabular}

\subsection{Attack intensity of leaf folder}

Attack intensity of leaf folder that was affected by plant density and water management were presented in Table 2 . Highest severity of leaf folder $(25 \%)$ was occurred in $42^{\text {nd }}$ DAT in high plant density with AWD. Leaf damage caused by this pest was firstly occurred at $18^{\text {th }}$ DAT, increased during tillering until day $42^{\text {nd }}$, but then decreased at generative phase of plant at day $63^{\text {rd }}$. Regarding the increase, severe damage was occurred at high plant density treatment. At another side, the increasing of leaf damage at low plant density was lower. Interesting result was shown at high plant density with AWD which presenting the highest severity (leaf damage) at day $42^{\text {nd }}$. It is suggested that high plant density gave favorable condition for leaf folder to actively feed. High plant density might result shady areas and high humidity of the paddy filed which favor their development and growth in one growing season. Some research reported that leaf damage by this pest could be reduced when the rice plant received enough water and the plant density is low [20].

Table 2. Attack intensity of leaf folder (\%) at 21st, 42nd and 63rd DAT

\begin{tabular}{lccc}
\hline \multirow{2}{*}{ Plant Density and Water Management } & \multicolumn{3}{c}{ Plant age (DAT) } \\
\cline { 2 - 4 } & 21st & 42nd & 63rd \\
\hline High plant density with continues flooding & $9.0 \mathrm{a}$ & $17.3 \mathrm{a}$ & $2.0 \mathrm{a}$ \\
High plant density with AWD & $17.5 \mathrm{~b}$ & $25.3 \mathrm{~b}$ & $8.8 \mathrm{~b}$ \\
Low plant density with continues flooding & $12.5 \mathrm{ab}$ & $19.5 \mathrm{ab}$ & $4.3 \mathrm{ab}$ \\
Low plant density with AWD & $15.5 \mathrm{ab}$ & $23.3 \mathrm{ab}$ & $4.3 \mathrm{ab}$ \\
\hline
\end{tabular}

\subsection{Severity of narrow brown spot}

Narrow brown spot severity that was affected by plant density and water management were presented in Table 3 . Highest severity of narrow brown spot $(58.0 \%)$ was found in $63^{\text {rd }}$ days after planting in plant with low density and continues flooding. The first symptom of this disease was occurred in vegetative phase at day $21^{\text {st }}$ after planting then increased at day $42^{\text {nd }}$ up to day $63^{\text {rd }}$. The most severe symptom was observed at generative phase, a month before harvest time. The increase of this disease severity was higher at continues flooding treatment than AWD treatment. It is suggested that the susceptible of plant and the infection rate of the pathogen was influenced by the environmental factors such as water and humidity of microclimate. It is similar to other research in North Sumatera and Central Java, reported that the disease incidence at some location was differ caused by environmental factors such as rainfall, nutrients, water, light, variety, and soil [21, 22]. 
Table 3. Severity of Leaf Folder (\%) at 21 st, 42 nd and 63rd DAT

\begin{tabular}{lccc}
\hline \multirow{2}{*}{ Plant Density and Water Management } & \multicolumn{3}{c}{ Plant age (DAT) } \\
\cline { 2 - 4 } & 21st & 42nd & 63rd \\
\hline High plant density with continues flooding & $17.0 \mathrm{ab}$ & $32.5 \mathrm{ab}$ & $49.3 \mathrm{ab}$ \\
High plant density with AWD & $11.5 \mathrm{a}$ & $26.3 \mathrm{a}$ & $45.0 \mathrm{a}$ \\
Low plant density with continues flooding & $24.0 \mathrm{~b}$ & $39.5 \mathrm{~b}$ & $58.0 \mathrm{~b}$ \\
Low plant density with AWD & $13.5 \mathrm{a}$ & $29.0 \mathrm{a}$ & $41.5 \mathrm{a}$ \\
\hline
\end{tabular}

\subsection{Rice yield}

The effect of plant density and water management to the rice yield was presented in Table 4. Highest yield (5.94 $\left.\mathrm{tha}^{-1}\right)$ was obtained from high plant density with continues flooding, while the lowest $\left(4.95 \mathrm{t} \mathrm{ha}^{-1}\right.$ ) was resulted from low plant density with continues flooding. It suggested that AWD resulted higher yield than continues flooding. This experiment result was similar to other research in South Sulawesi, reported that the yield of Inpari 13 was higher in AWD water management compares to continues flooding [23]. In addition, AWD reduces irrigation water use up to $30 \%$ without reducing yield [24, 25].

Table 4. The yield of rice

\begin{tabular}{lc}
\hline \multicolumn{1}{c}{ Plant Density and Water Management } & Yield (t ha $\left.\mathbf{~ a}^{-1}\right)$ \\
\hline High plant density with continues flooding & $5.94 \mathrm{a}$ \\
High plant density with AWD & $5.10 \mathrm{ab}$ \\
Low plant density with continues flooding & $4.95 \mathrm{~b}$ \\
Low plant density with AWD & $5.70 \mathrm{a}$ \\
\hline
\end{tabular}

\section{Conclusion}

High leaf folder attack intensity was caused by high plant density, but not effected by water management. At the other side, high severity of narrow brown spot was affected by water management, but not effected by plant density. The highest attack intensity of leaf folder $(25 \%)$ was occurred at $42^{\text {nd }}$ DAT in high plant density with AWD. While the highest severity of narrow brown spot (58\%) was found at $63^{\text {rd }}$ DAT in plant with low density and continues flooding.

\section{References}

1. Indonesia Statistic Bureau, Statistical Year Book of Indonesia (2020)

2. I. Dwipa, A. Syarif, I. Suliansyah, E. Swasti. Biodiversitas 19, 3 (2018).

3. A.S. Wijaya, Perbanyakan Corynebacterium sp. dan Cara Aplikasinya Di Laboratorium Balai Proteksi Tanaman Pertanian (BPTP) Bantul Provinsi Daerah Istimewa Yogyakarta. Skripsi. Surakarta: Faperta UNS (2011).

4. I.R. Manurung, M.I. Pinem, L. Lubis. Agroekoteknologi 2, 4 (2014).

5. A.N. Imrosi, AN., P.A. Mihardjo, M. Hoesain. Berkala Ilmiah Pertanian 10, (2015)

6. M.S.H. Prasetyo, Kajian Intensitas Penyakit Bercak Coklat Sempit (Cercospora oryzae) dan Teknik Pengendaliannya pada Pertanaman Padi di Kecamatan Tanggul Kabupaten Jember. Skripsi. Jember: Faperta Universitas Jember (2017)

7. D.E. Groth, C. Hollier, Narrow brown leaf spot of rice. In: Louisiana Plant Pathology: Identification and Management Series. Pub. 3105. LSU AgCenter, Baton Rouge (2010). 
8. K. Gunathilagaraj, M. Gopalan. Intl. Rice Res. Notes 11, 6 (1986)

9. S.J. Luo. Plant Diseases and Pests, 1 (2010).

10. V.K. Nanda, R.C. Bisoi. J. Agrl. Res. 3, 2 (1990).

11. S. Shah, M. Ali, U.H. Rehman, A. Rehman, F.M. Abbasi, I.H. Khalil, A. Ali. Sarh. J. Agric. 24, 1 (2008).

12. M.R. Khan, M. Ahmad, S. Ahmad. Pakistan J. Agric. Sci. 26 (1989).

13. S.M. Alvi, M.A. Ali, S. Chaudhary, S. Iqbal, Int. J. Agric. Biol., 5 (2003).

14. R.C. Bautista, E.A. Heinrichs, R.S. Rejesus. Environ. Entomol. 13 (1984).

15. R.Rajendran, S. Rajendran, P.C. Sandra. Intl. Rice Res. News 11, 17 (1986)

16. S. Maragesan, S. Chellish. Indian J. Agri. Sci., 56 (1987)

17. M.N. Bhatti, Pakistan Entomol. 17 (1995)

18. R.K. Gangwar. J. of Natural Sci. Res., 5, 5 (2015).

19. C. Padmavathi, G. Katti, V. Sailaja, A.P. Padmakumari, V. Jhansilakshmi, M. Prabhakar, YG. Prasad. J. Insect Sci. 13, 1 (2013).

20. R.K. Gangwar. J. of Natural Sci. Res. 5, 15 (2015).

21. F.A.S. Simanjuntak, I. Safitri, D. Bakti. Distribution of narrow brown leaf spot disease of rice (Cercospora oryzae Miyake) in North Sumatra. IOP Conf. Series: Earth and Environmental Science 454 (2020)

22. N. Lakshita, S.H. Poromarto, H. Hadiwiyono. Agrotech Res J. 3, 2 (2019).

23. M. Taufik, Arafah, B. Nappu, F. Djufry. Jurnal Pengkajian dan Pengembangan Teknologi Pertanian 17, 1 (2014).

24. M.A. Ali, M.A. Hoque, P.J. Kim. Ambio. 42 (2013).

25. E. Sanchis, M. Ferrer, A.G. Torres, M. Cambra-López, S. Calvet. Environ. Engineering Sci., 29 (2012). 